\title{
Radial Variation in Selected Wood Properties of Indonesian Merkusii Pine ${ }^{1}$
}

\author{
Wayan Darmawan $\mathbb{D}^{2, \dagger} \cdot$ Dodi Nandika ${ }^{2} \cdot$ Britty Datin Hasna Afaf $^{2} \cdot$ \\ Istie Rahayu $^{2} \cdot$ Dumasari Lumongga $^{3}$
}

\begin{abstract}
Merkusii pine wood (Pinus merkusii) was extensively planted throughout Indonesia, where it is only indigenous in northern Sumatera, by the Dutch during colonial times. The demand for this wood species, especially in the domestic market, has increased notably, despite its limited durability regarding decay resistance. The purpose of this study was to investigate the occurrence of juvenile and mature wood on merkusii pine and to analyze its radial features from pith to bark based on density, shrinkage, static bending in modulus of rupture and modulus of elasticity, fiber length, microfibril angle, and durability. A segmented modeling approach was used to find the juvenile-mature transition. The graveyard test was performed to characterize the termite resistance from pith to bark of merkusii pine. The maturations were estimated to start at radial increments of $15 \mathrm{~cm}$ from the pith by fiber length and of $12 \mathrm{~cm}$ from the pith by microfibril angle. The projected figures for the proportion of juvenile wood at breast height were around $65 \%$. The results also indicate that the pine wood was $0.52 \mathrm{~g} / \mathrm{cm}^{3}$ in density, 1.45 in coefficient of anisotropy, which indicates its good stability, $7597 \mathrm{MPa}$ in modulus of elasticity, and $63 \mathrm{MPa}$ in modulus of rupture. Natural durability against subterranean termite of the merkusii pine wood was rated to be grade 4 to 0 from pith to bark. However, after being treated by Entiblu and Enborer preservatives, its rating increased to grade 10 to 9 .
\end{abstract}

Keywords: merkusii pine-fiber length-microfibril angle-juvenile and mature-termite resistance

\section{INTRODUCTION}

Merkusii pine (Pinus merkusii) is one of the most important tropical softwood tree species in Indonesia. Although it is only indigenous in northern Sumatera between $1^{\circ} 40^{\prime}$ and $2^{\circ} 06^{\prime} \mathrm{S}$ latitude, merkusii pine was extensively planted in Indonesia by the Dutch during colonial times. Indonesian government has continued this practice especially in Java as merkusii pine is the most important producer of pine resin. Indonesia is a major producer of turpentines distilled from this resin. The average breast height diameter for merkusii pine at the age of 40 years is around $38 \mathrm{~cm}$, and the branch-free trunk height is between 8 to $10 \mathrm{~m}$ at this age. Therefore, the mean diameter growth for the merkusii pine is about $0.95 \mathrm{~cm} /$ year $(0.374 \mathrm{inch} /$ year), which renders it a fast-growing wood species. Teck and Hilt (1990) reported that the growth diameters of

\footnotetext{
${ }^{1}$ Date Received March 5, 2018, Date Accepted July 2, 2018

2 Department of Forest Products, Faculty of Forestry, Bogor Agricultural University (IPB), Bogor (16680), Indonesia

${ }^{3}$ Research Assistant, Faculty of Agriculture, Muhammadiyah University, Purwokerto, Indonesia

$\dagger$ Corresponding author: Wayan Darmawan (e-mail: wayandar@indo.net.id, ORCID: 0000-0001-9603-2725)
} 
red pine, white pine, Virginia pine, and loblolly pine were $0.138,0.159,0.116$, and 0.122 inch/year, respectively. Differences in the diameter growth between pine tree species stem from the effects of genotype, environment, and the interaction between both variables.

When merkusii pine trees have grown beyond good yield of resin (in age rotations of 35 to 40 years), they are harvested and processed for wood products. Merkusii pine trees harvested at these age rotations can be expected to contain a high proportion of juvenile wood. The juvenile period for specific gravity in red pine may approach 70 years in some stands (Shepard and Shottafer, 1992). Seo et al. (2014) found that tracheid length for Korean red pine took approximately 25 and 40 years for V and VIIII age class stands, respectively, until the length was stabilized. The juvenile portion of the tree stem surrounding the pith is characterized by a progressive change in cell features and wood properties (Evans, 2000; Lachenbruch et al., 2011). In comparison with mature wood, juvenile wood is made of smaller and shorter fibers with thinner walls and larger microfibril angles, lower density, and lower strength properties (Koubaa et al., 2005; Clark et al., 2006; Adamopoulus et al., 2007; Gryc et al., 2011; Fajriani et al., 2013). It is well known that the inherent characteristics of juvenile wood contribute to the development of undesirable solid wood properties. Despite being acceptable for products such as newsprint and quality printing paper (Zobel, 1984), juvenile wood may cause serious problems for quality products, especially veneer or solid wood products. One of the most serious problems that arises from drying and using young plantation grown conifers is the formation of warps such as twists, crooks, and bows (Kliger, 2001; Johansson \& Kliger, 2002).

Radial variation from pith to bark in wood traits such as density, fiber length, microfibril angle, longitudinal shrinkage, ring width, and latewood proportion is frequently described in terms of juvenile and mature wood zones and is used to estimate the transition age. Several methods have been proposed to estimate the transition age from juvenile to mature wood. The simplest method is the so-called threshold or graphic method. A threshold value of a trait is selected to define where the trait has reached the mature age (Clark et al., 2006). Other methods are based on segmented regression models (Tasissa and Burkhart, 1998; Darmawan et al., 2013; Sauter et al., 1999) or nonlinear mixed-effects models (Mutz et al., 2004; Mora et al., 2007; Adamopoulos et al., 2011). Gapare et al. (2006) noted that segmented regression analysis proves to be a practical and objective method to estimate cambial age of transition from juvenile to mature wood in a study of radiata pine. The threshold method requires having properties of a minimum specified value that can relate to a final product, whereas the segmented approach defines mature wood on the basis of the rate of change of a property. Other methods use mathematical and numerical approaches that produce a unique polynomial function from each pith-to-bark profile (Koubaa et al., 2005). Kwon et al. (2013) reported that the utilization of light microscopy and fast fourier transform (FFT) for microfibril angle measurement from the unstained sections of red pine (Pinus densiflora) can be more repeatable and less subjective than those from the manual angle measurement.

Merkusii pine does not afford distinct growth rings, and more than one growth rings can be observed in a year. Detailed information on growth rates and maturation ages of merkusii pine, which is important to gain a better understanding of its functioning, is scarce. Therefore, the investigation of the juvenile and mature transition and characterization of their properties is of interest for enhanced exploitation of merkusii pine wood.

Untreated merkusii pine wood was classified as 
non-durable and liable to termites attack according to Martawijaya et al. (2005). Decay resistance can vary according to the radial position from which an item of wood is taken. In some species, the resistance of the outer heartwood increases markedly from the upper to the lower trunk. Radial differences in resistance can vary significantly, being more notable in larger trees, with the lowest resistance occurring in the innermost wood (Zabel and Morrell, 1992). This rate of resistance has been thought to be influenced by the amount of extractives deposited in the heartwood and sapwood. Therefore, a better understanding on the radial variation of extractive content from pith to bark and in the nature of decay rate of merkusii pine was determined.

The aim of this study was to characterize the profiles and average trends in density, shrinkage, fiber length, microfibril angle (MFA), modulus of rupture (MOR), modulus of elasticity (MOE), extractive content, and durability of untreated and treated merkusii pine as a function of radial increments from pith to bark.

\section{MATERIALS and METHODS}

\subsection{Sample tree origin}

Sample trees were obtained from plantation forests managed by the Bogor Agricultural University. The plantation sites were located at Sukabumi $\left(6.9^{\circ} \mathrm{S}, 106.8^{\circ}\right.$ E, $550 \mathrm{~m}$ above sea level) West Java. Sukabumi West Java has annual rainfall ranges between 1600-4000 mm (average annual rainfall $2400 \mathrm{~mm}$ ) with an average temperature of $23{ }^{\circ} \mathrm{C}$. Three trees were selected from the plantation site as representative specimens. The sample trees, which had straight stems and were free from external defects, were selected to minimize tree-to-tree variation. The sample trees were 40 years of age and had a height of branch-free stem ranging from 8 to $10 \mathrm{~m}$ and average diameters at breast height level (1.3 m above ground level) of $38 \mathrm{~cm}$. After felling the trees, one log section of $2 \mathrm{~m}$ in length was taken from each tree at the bottom part of the stem. The sample logs were wrapped in plastic, kept cold, and maintained in the green condition before they were transported to the wood workshop for the preparation of test specimens.

\subsection{Specimen preparation}

Tree annual rings have been used for a long time in areas outside the tropics to determine the transition point between juvenile and mature wood. Considering the fact that growth rings are not present in merkusii pine, we decided to apply a radial increment method, which would be more practical for characterizing the juvenile and mature wood. Radial increments of 1 or $2.5 \mathrm{~cm}$ were marked from pith to bark and numbered consecutively as shown in Fig. 1. The width of the radial increments for fiber length and MFA measurements was $1 \mathrm{~cm}$, and that for the measurement of other traits was $2.5 \mathrm{~cm}$. Wood traits (density, shrinkage, fiber length, MFA, MOE, MOR, and decay resistance) were measured at each radial increment and used to characterize the juvenile and mature merkusii pine wood.

Three sample disks of $2 \mathrm{~cm}$ thickness (Fig. 1-A1) were cross-cut from the bottom part of the sample logs using a band saw. Other sample disks of $50 \mathrm{~cm}$ thickness (Fig. 1-B1) were cut from the rest of the logs. From the A1 disks, flitches of $2.0 \mathrm{~cm}$ in the tangential (T) direction were prepared from bark to bark through the pith using a band saw for fiber length and MFA measurements (Fig. 1-A2). The flitches were cut into segments of $1 \mathrm{~cm}$ in the radial (R) direction from pith to bark and numbered consecutively. The individual segments for the juvenile mature test specimens (fiber length and MFA) were kept in the green condition (Fig. 1-A3). From the B1 disks, boards of $2.5 \mathrm{~cm}$ thickness in the tangential direction were bandsawn bark to bark 


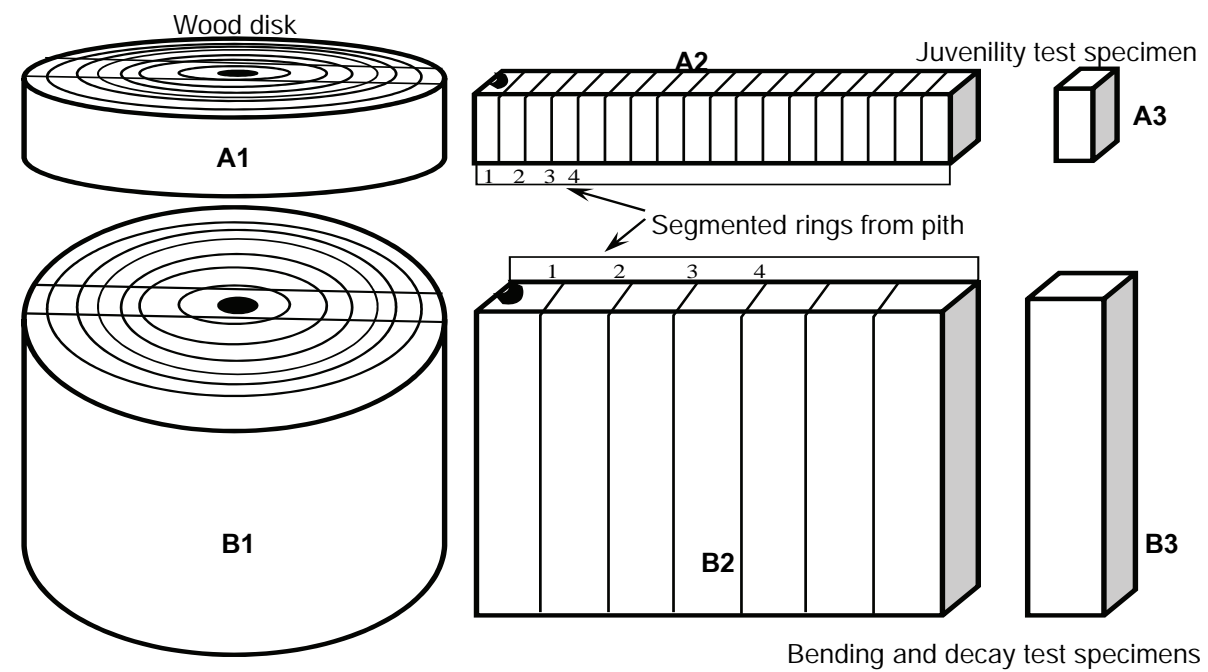

Fig. 1. Schematic drawing of the preparation of the test specimens. $\mathrm{R}=$ radial, $\mathrm{T}=$ tangential, $\mathrm{L}=$ longitudinal.

through the pith (Fig. 1-B2). The boards were also re-sawn into segments of $2.5 \mathrm{~cm}$ in the radial direction from pith to bark and numbered consecutively. The square boards (Fig. 1-B3) were carefully air-dried to prevent warping and used for performing the tests of density, shrinkage, static bending (MOE/MOR), and decay resistance.

\subsection{Density and shrinkage measurement}

Density and shrinkage profiles from pith to bark were measured on the basis of the BS 373-1957 testing procedure. The square boards (Fig. 1-B3) were planed into $2 \times 2 \times 50 \mathrm{~cm}$. Density and shrinkage test specimens $(2 \times 2 \times 5 \mathrm{~cm})$ were cut from the planed boards. Five test specimens were used for the measurements. Air-dried (moisture content 15\%) density values from each radial increment were calculated and used to calculate the density profiles from pith to bark. Shrinkage after air drying (moisture content 15\%) was measured from pith to bark in radial, tangential, and longitudinal directions.

\subsection{Static Bending Test Measurement}

Air-dried bending test specimens $(2 \times 2 \times 30 \mathrm{~cm})$, straight-grained and free from any visible defects, were prepared from the planed boards (Fig. 1-B3) with true radial and tangential surfaces. The bending test specimens were numbered consecutively from pith to bark. Static bending tests were conducted on an Instron universal testing machine according to the BS 373-1957 testing procedure.

\subsection{Fiber length and MFA measurement}

Juvenile to mature test specimens (Fig. 1-A3) were used to characterize fiber length and MFA from pith to bark. Small pieces from the test specimens were macerated following Schulze's method (TAPPI 1991). Thus, the small pieces were treated with nitric acid and a small quantity of potassium chlorate to dissolve the middle lamella, thereby allowing the fibers to become separated from one another. The macerated fiber suspension was placed on a microscope slide by means 
of a needle dropper according to the TAPPI T401 om-88 procedure (TAPPI 1991a). Thirty slides of macerated fiber were prepared from each juvenile and mature test specimen. The slides were then dried and a cover glass was placed over the fiber, and the fiber length was measured under an optical video microscope. Undamaged single fibers were selected from each slide, and their images were captured. The captured images were analyzed using Motic image software for measuring the fiber length.

The juvenile mature test specimens (Fig. 1-A3) were microtomed to produce undamaged thin tangential sections $30 \mu \mathrm{m}$ thick. Fifteen slides were prepared from each juvenile mature test specimen. The slides were analyzed under a polarization microscope and cells presenting clear microfibrils were imaged and analyzed using Motic image software for measuring the angle of the microfibrils.

A segmented regression model was used to determine the transition radial increment from juvenile to mature wood. It was assumed that the development of fiber length and MFA from pith to bark can be described by two functions in a curve. The first function is a steep slope of the curve over the first years beginning at the pith (juvenile wood), and the second function is a constant slope for the later part of the curve (mature wood). The fitted regression model for the functions takes the form of a quadratic model with a plateau. The transition radial increment was directly obtained by using nonlinear least squares procedures (PROC NLIN) in SAS STAT (SAS Institute 2004).

\subsection{Extractive content measurement}

Extractive content of each radial section from pith to bark was determined by using ethanol/benzene extraction method. Ethanol/benzene extractives were extracted from $10 \mathrm{~g}$ of 50 mesh wood powder from each radial section of merkusii pine following TAPPI
T204 om-88 procedures (TAPPI 1991b). The extractive contents were calculated on the basis of the percentage of extract dry weight to powder dry weight.

\subsection{Preservatives treatment and graveyard test}

Air-dried decay test specimens $(2.5 \times 2.5 \times 46.0$ $\mathrm{cm})$ were prepared from the planed boards (Fig. 1-B3). Both untreated and treated test specimens were numbered consecutively from pith to bark. The preservatives used for the treated test specimens were Entiblu 450/100SC, which contains a fungicide compound consisting of chlorotalonyl $450 \mathrm{~g} / \mathrm{L}$ and carbendazim $100 \mathrm{~g} / \mathrm{L}$ that serves to prevent fungal attacks, and Enborer 100EC containing a cypermethrin $100 \mathrm{~g} / \mathrm{L}$ insecticide, which prevents termite attacks. Three test specimens were immersed into preservative solutions of $1 \mathrm{~L}$ Entiblu in $20 \mathrm{~L}$ water, $1 \mathrm{~L}$ Enborer in $20 \mathrm{~L}$ water, and a combination $0.5 \mathrm{~L}$ Entiblu and $0.5 \mathrm{~L}$ Enborer in $20 \mathrm{~L}$ water for 48 hours. The treated test specimens were air-dried and their retentions were calculated.

The graveyard test was carried out according to ASTM D1758-05 (2005). The untreated and treated wood specimens were evaluated on the basis of average weight loss of the test specimens and the percent loss of cross section when they were partially buried in outdoor ground contact. The specimens were buried up to two third (2/3) of their lengths in the ground. The stakes were put in rows at a distance of approximately $50 \mathrm{~cm}$ from each other and the different specimens were installed alternately. All specimens were free of cracks, decay, and other obvious defects. Decay was assessed after four months and their percent of weight loss due to subterranean termite (Coptotermes curvignathus Holmgren) attack and the percent loss of cross section were calculated. Termite resistances of the samples were rated from the percent loss of cross section according to ASTM D1758-05 (Table 1). 
Table 1. ASTM D1758-05 termite grade rating of field test specimens

\begin{tabular}{cl}
\hline $\begin{array}{c}\text { Visual } \\
\text { Rating }\end{array}$ & \multicolumn{1}{c}{ Description of condition } \\
\hline \hline 10 & $\begin{array}{l}\text { Sound timber, no termite attack } \\
9\end{array}$ \\
$\begin{array}{l}\text { Trace of termite attack less than } 3 \% \text { of } \\
\text { cross section }\end{array}$ \\
8 & Termite attack $3 \%$ to $10 \%$ of cross section \\
7 & Termite attack $10 \%$ to $30 \%$ of cross section \\
6 & Termite attack $30 \%$ to $50 \%$ of cross section \\
4 & Termite attack $50 \%$ to $75 \%$ of cross section \\
0 & Failure due to termite attack \\
\hline
\end{tabular}

\section{RESULTS and DISCUSSION}

\subsection{Density and shrinkage}

The results in Fig. 2a indicate that the density increased proportionally from pith to bark. The green density of merkusii pine wood close to the pith was $0.53 \mathrm{~g} / \mathrm{cm}^{3}$, and its air-dry density was $0.43 \mathrm{~g} / \mathrm{cm}^{3}$. The green and air-dry density of wood immediately inside the bark was 0.82 and $0.66 \mathrm{~g} / \mathrm{cm}^{3}$, respectively. The average density from pith to bark for the green and air-dry condition was 0.63 and $0.52 \mathrm{~g} / \mathrm{cm}^{3}$, respectively. Martawijaya et al. (2005) found the air-dry density of merkusii pine wood to range from 0.40 to $0.75 \mathrm{~g} / \mathrm{cm}^{3}$ with an average of $0.55 \mathrm{~g} / \mathrm{cm}^{3}$. Therefore, our results regarding the density of merkusii pine are within the range reported in the literature. For further development of merkusii pine plantation, fast-growing provenances or clones could be selected, and matching the provenances for specific site conditions and silvicultural requirements appears to be important in merkusii pine improvement programs.

The trend in variations of air-dry shrinkage for merkusii pine from pith to bark is presented in Fig. 2b. The mean values obtained for shrinkage in the longitudinal, radial, and tangential directions were $0.23 \%, 2.35 \%$, and $3.45 \%$, respectively. The coefficient of anisotropy (ratio of tangential to radial shrinkage) was 1.45. This coefficient indicates that merkusii pine has a lower degree of anisotropy, which could lead to improved dimensional stability. Tsoumis (1991) also found that, in woods of higher density, the difference between tangential and radial shrinkage is smaller. The light weight (medium density) and the good stability of merkusii pine renders it a good option as core material for applications in engineering doors and even high quality interior furniture.

The trends from pith to bark depicted in Fig. 2 show that density and shrinkage were not suitable for a clear differentiation between juvenile and mature wood of merkusii pine. When the segmented regression model was applied, it was deduced that the use of radial increment for density and shrinkage was not appropriate because it led to low coefficients of determination and a large range of transition radial increments.

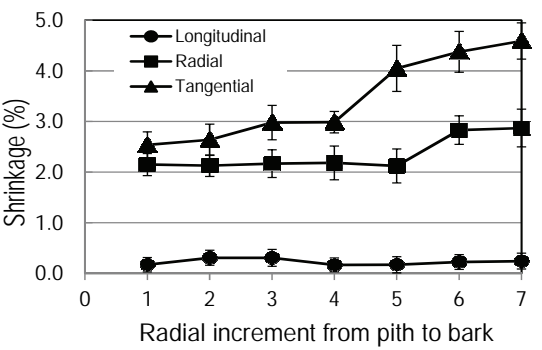

(b)

Fig. 2. Average density (a) and shrinkage (b) variations from pith to bark for Merkusii pine. 


\subsection{Fiber length}

Profiles of fiber length at $1.3 \mathrm{~m}$ height from pith to bark are presented in Fig. 3. At every radial increment, the length of 30 individual fibers was measured. The results in Fig. 3 indicate that the fibers varied in length for each radial increment for merkusii pine. In the first radial increment of the stems at $1.3 \mathrm{~m}$ height, all fibers were larger than $2 \mathrm{~mm}$ length. In general, it was found that the fiber lengths at $1.3 \mathrm{~m}$ height varied following a similar pattern from pith to bark.

The average values of fiber length at each radial increment were calculated, and the results are plotted as the line in Fig. 3. The average fiber length values of the first to seventh radial increments were less than $5 \mathrm{~mm}$, whereas in the eighth radial increment they exceeded $5 \mathrm{~mm}$. The mean fiber length value of merkusii pine started at $2066 \mu \mathrm{m}$ from the first radial increment. The fiber length increased markedly up to the tenth radial increment. From this point, the fiber lengths increased gradually. This profile displays clearly the expected transition age. The average fiber length at $1.3 \mathrm{~m}$ stem height from pith to bark at the age of 40 years was calculated to be $4974 \mu \mathrm{m}$ for merkusii pine. This finding was close to the value of $5450 \mu \mathrm{m}$ that Martawijaya et al. (2005) reported

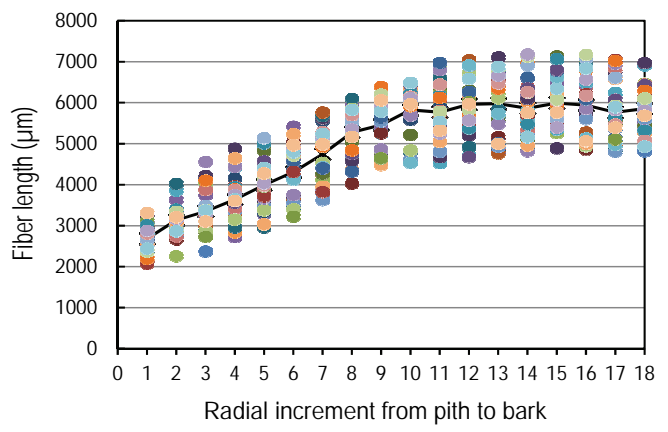

Fig. 3. Profiles of fiber length from pith to bark for Merkusii pine tree. The symbols mark the variation of fiber length among 30 individual fibers in each radial increment. for merkusii pine wood.

The procedure "non-linear" (PROC NLIN) of SAS 9.1.3 was applied for the average results in Fig. 3 to determine the juvenile to mature wood transition radial increment. The model produced by the PROC NLIN was a quadratic function of $\mathrm{Y}=18.59 \mathrm{X}^{2}+544.70 \mathrm{X}$ +1958.70 and a plateau function of $\mathrm{Y}=5946.97$ at $X=14.64$, with $R^{2}=0.97$. The result of this analysis suggests that the fiber length was an appropriate trait to determine the transition radial increments of merkusii pine. The transition was estimated to occur at the radial increment 14.64. The stems of merkusii pine could contain mature fibers at the radial increment 15 (at a diameter of $30 \mathrm{~cm}$ ). This result indicates that tree stems of merkusii pine were about $65 \%$ juvenile at the age tested (40 years). With respect to the juvenile wood portion of the stems, the mean fiber lengths of juvenile and mature wood were calculated to be 4623 $\mu \mathrm{m}$ and $5883 \mu \mathrm{m}$ at $1.3 \mathrm{~m}$ stem height, respectively. The portion of juvenile wood in the stems of merkusii pine would play an important role in determining the exploitation age, which is mainly dependent on the number of radial increments comprising the juvenile wood. Merkusii pine trees throughout Indonesia are felled at ages below 40 years for pulp wood industries, since it is considered that the trees have grown beyond good yield of resin at this age.

\subsection{Microfibril angle}

In Fig. 4, the plot of MFA versus radial increment for merkusii pine trees is depicted. The MFA varied from $30^{\circ}$ to $35^{\circ}$ (average of $33^{\circ}$ ) near the pith and from to $17^{\circ}$ to $23^{\circ}$ (average of $20^{\circ}$ ) near the bark. The average values of MFA in each segment were calculated, and the results are plotted as the line in Fig. 4. In contrast to the fiber length, the profiles of MFA decreased exponentially from pith to bark. The average MFA values in Fig. 4 decreased steeply from 


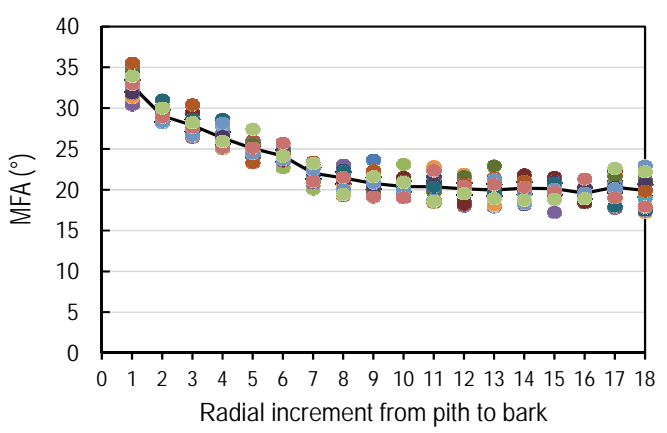

Fig. 4. Profiles of MFA from pith to bark for Merkusii pine tree. The symbols mark the variation of MFA among 15 individual fibers in each radial increment.

the pith up to a radial increment of nine, then decreased gradually toward the bark. Beyond the ninth radial increment, the microfibril angles for both teaks decreased with angles almost below $19^{\circ}$. These results suggest that the microfibril angles in the stems of merkusii pine stabilize at values lower than $19^{\circ}$.

MFA, as in the case of the fiber length, proved to be an appropriate trait to define the juvenile to mature transition radial increment. The transition radial increment was also calculated by the segmented regression model. The model produced by the PROC NLIN was a quadratic fuction of $\mathrm{Y}=0.10 \mathrm{X}^{2}-2.43 \mathrm{X}$ +34.42 and a plateau function of $\mathrm{Y}=20.05$ at $\mathrm{X}=$ 11.83 with $\mathrm{R}^{2}=0.98$. The transition was estimated to occur at the radial increment 11.83 . This result

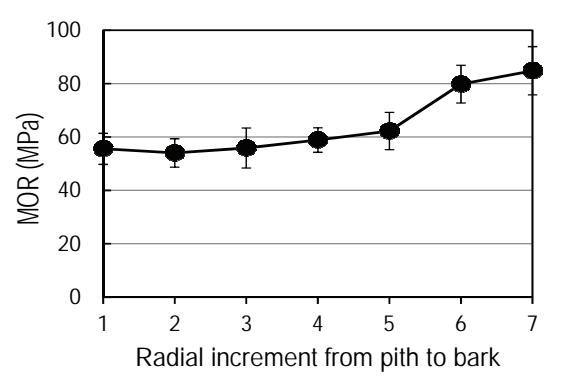

(a) suggests that the stems of merkusii pine could be estimated to contain mature microfibril angles at the radial increment 13 (at a diameter of $26 \mathrm{~cm}$ ). Therefore, the juvenile wood portions in the stem were found to be $55 \%$ for merkusii pine. The mean MFA values of juvenile and mature wood were calculated to be $24.2^{\circ}$ and $20.0^{\circ}$, respectively, at $1.3 \mathrm{~m}$ tree stem height.

\subsection{MOE and MOR}

The variations of MOR and MOE from pith to bark for merkusii pine are presented in Fig. 5. The results indicate that juvenile woods of merkusii pine had a lower MOR and MOE near the pith than near the bark, due to the presence of larger microfibril angles and lower density near the pith. However, the proportional increase of MOR and MOE from pith to bark precluded their use as reliable juvenile to mature wood transition indicators. The mean MOE value from pith to bark for merkusii pine wood calculated in this study was $7597 \mathrm{MPa}$, and its mean MOR value was $63 \mathrm{MPa}$. Burdon et al. (2001) found that the average MOR and MOE of radiata pine from pith to bark were $7851 \mathrm{MPa}$ and $68 \mathrm{MPa}$, respectively, which were fairly similar to those obtained in this study for merkusii pine wood. Meanwhile, merkusii pine exhibited a lower MOR value than Korean red pine (76.5 MPa) (Kim et al., 2014), which could be due to the lower age of the former

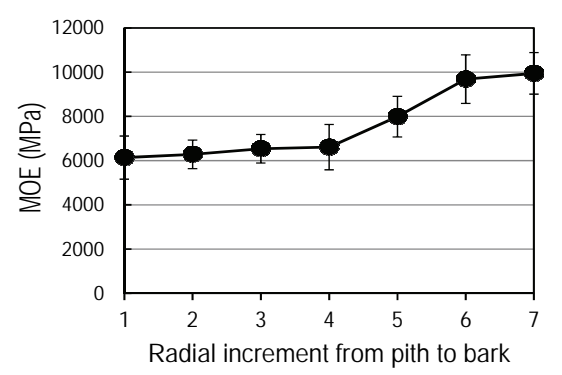

(b)

Fig. 5. Development of mean MOR (a) and MOE (b) from pith to bark for Merkusii pine tree. 
Radial Variation in Selected Wood Properties of Indonesian Merkusii Pine

Table 2. Other mechanical properties of Merkusii pine and Korean red pine

\begin{tabular}{cccccc}
\hline Species & $\begin{array}{c}\text { Compressive } \\
\text { strength }\left(\mathrm{N} / \mathrm{mm}^{2}\right)\end{array}$ & $\begin{array}{c}\text { Shearing strength } \\
\left(\mathrm{N} / \mathrm{mm}^{2}\right)\end{array}$ & $\begin{array}{c}\text { Cross section } \\
\text { Hardness }\left(\mathrm{N} / \mathrm{mm}^{2}\right)\end{array}$ & $\begin{array}{c}\text { Cleavage strength } \\
(\mathrm{MPa})\end{array}$ & $\begin{array}{c}\text { Tension perpendicular } \\
\text { the grain }(\mathrm{MPa})\end{array}$ \\
\hline \hline Merkusii pine* & 44.0 & 9.1 & 47.9 & 5.5 & 4.2 \\
Korean red pine** & 36.2 & 9.8 & 43.7 & NA & NA \\
\hline
\end{tabular}

Note : * Reported by Martawijaya at al. (2005)

**Reported by Kim et al. (2014)

NA (not available)

wood (40 years) compared with the latter (108 years). However, considering the previous results listed in Table 2, the mechanical properties of merkusii pine are comparable to those of Korean red pine.

\subsection{Variation of transition radial increment with traits}

The transition radial increment for merkusii pine was calculated by applying a segmented regression model to fiber length and MFA, as described above. Two different results for the transition radial increment at $1.3 \mathrm{~m}$ sampling height were obtained. Thus, the transition radial increment determined from MFA was three radial increments lower than the transition age determined from fiber length, which confirms that the determination of transition radial increment was dependent on the trait considered. Nevertheless, although fiber length and MFA have different radial patterns, the transition value found for the two traits was not remarkably different.

The values of density, shrinkage, fiber length, MFA, and bending strength of merkusii pine obtained in this study are expected to provide practical information for processors and silviculturists, leading to a more appropriate usage of merkusii pine trees. The presence of juvenile wood must be taken into consideration with respect to the use of merkusii pine for construction purposes, particularly since bending and dynamic strength properties are critically important factors. Thus, the strength properties of merkusii pine trees depend on their juvenile wood contents, which would provide lower strength. Several studies completed on solid-sawn lumber have provided a good understanding of how juvenile wood affects the mechanical properties of solid-sawn lumber (Biblis, 1990; MacPeak et al., 1990; Kretschmann and Bendtsen, 1992).

\subsection{Extractive contents and decay resistance}

Extractive, a naturally occurring minor constituent of wood, is essential for the protection of wood from decay by wood-destroying organisms. As can be seen in Fig. 6a, the ethanol/benzene extractive content of merkusii pine increased from pith to bark. The average extractive content of the radial ring number 1 was $5.9 \%$ and that of the radial ring number 6 was $1.8 \%$. For rings 1-4, which contained almost the same amount of extractive, the extractive content was higher than for other radial rings. This difference could be due to the greater amount of heartwood present in the radial rings 1-4. It was previously reported that the ethanol/ benzene extractive content also exhibited radial variation (Stringer and Olson, 1987; Gierlinger and Wimmer, 2004); sapwood tissue possesses the lowest ethanol/benzene extractive content (2.70\%), whereas inner and outer heartwood tissues maintain higher extractive levels, $4.10 \%$ and $4.60 \%$, respectively.

The results in Fig. $6 \mathrm{~b}$ show that the retention of chemical preservatives (Enborer, Entiblu, and the combination of both) increased from pith to bark. The 


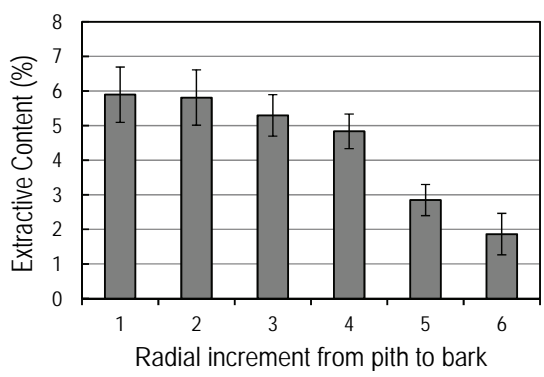

(a)

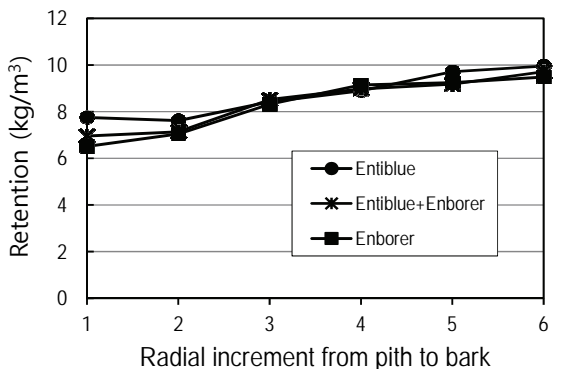

(b)

Fig. 6. Variation of extractive (a) and retention of chemical preservative (b) from pith to bark for Merkusii pine.

preservative retention into air-dried merkusii pine wood should be correlated to the wood extractive content. On the basis of weight gain retention, the preservative solutions in wood samples near the pith gave much poorer weight gain retention than the wood samples near the bark. Since the juvenile merkusii pine wood was more abundant in the first 11 radial rings of the heartwood, it was considered that the low preservative retention of $8 \mathrm{~kg} / \mathrm{m}^{3}$ was due to the heartwood. The pine heartwood is specific for phenolic compounds such as stilbenoids and flavonoids (Chang et al., 1999; Wang et al., 2004). It is also possible that hydrophobic resin acids present in the heartwood area may impede the penetration of preservatives. Winandy et al. (2001) reported that the one- to two-year transition wood between the heartwood and sapwood for Southern pine is sometimes difficult to treat, and they also noted that a microscopic evaluation showed indications of partial pit in crustation by phenolics. Previous reports on the treatment of Southern pines have shown that the heartwood is more difficult to treat than sapwood (Choong and Fogg, 1972). In the mature trees of the Southern pine, there are highly significant differences in permeability between pith and bark, with that near the pith being lower than that in the sapwood near the bark.

Natural resistance is the inherent ability of some wood species to resist the attack of bio-deteriorating agents without treatment with chemical preservatives. The natural resistance exhibited by some species stems from the presence of extractives in the heartwood region. The natural durability of most heartwood is enhanced by the presence of toxic extractive components, which vary between species and determine their level of durability (Carter et al., 1978; McDaniel, 1992; Taylor et al., 2006; Santana et al., 2010). For example, in yellow-hearted pine (Pinus densiflora for. erecta Uyeki), the weight loss of the heartwood after fungi and termite test was reported to be much lower than that of the sapwood (Lee at al., 2017). Furthermore, the highest termite mortality was obtained from the heartwood of yellow-hearted pine. Accordingly, Fig. 7 reveals that the weight loss of untreated stakes of merkusii pine increased from pith to bark. As its extractive content decreased (Fig. 6), the weight loss of stakes increased, implying that higher extractive content of Merkusii pine wood stakes would afford a correspondingly lower weight loss. The average weight loss of untreated samples was $26 \%$ and $51 \%$ for the stake near the pith and near the bark, respectively (Fig. 7a). The untreated wood samples near the pith had also better rating of subterranean termite grade (4.3) than near the bark (1.3) during four months of field test (Fig. 7b). This confirmed the assertion that no wood is completely resistant to 


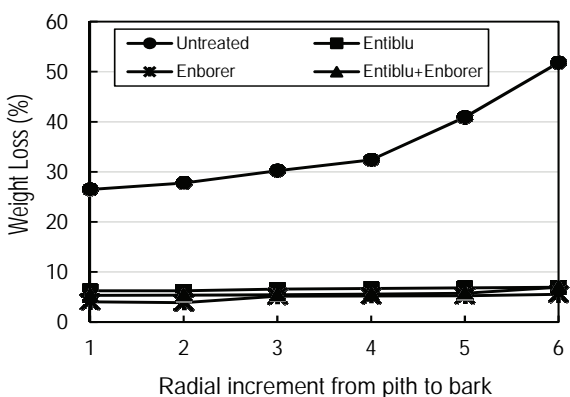

(a)

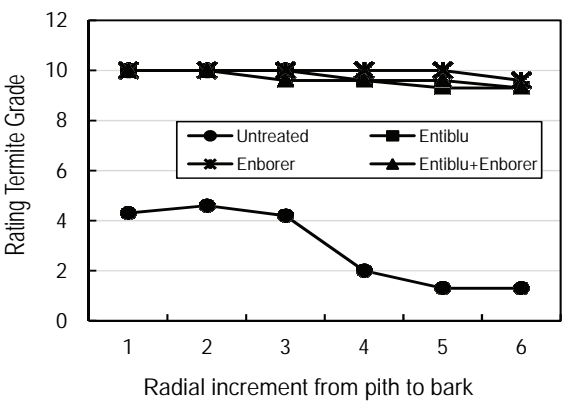

(b)

Fig. 7. Variation of weight loss (a) and termite grade rating (b) of untreated and preservative treated from pith to bark for Merkusii pine.

the attack of termites, only the degree of resistance varies. Therefore, a better decay resistance or longer service life of merkusii pine should be enhanced through the use of chemical preservatives.

Weight losses of merkusii pine wood treated with preservatives of Entiblu, Enborer, and their combination from pith to bark are showed in Fig. 7a. The weight loss of the untreated stakes was more than 300\% higher than that of the treated wood stake. The results of T-test indicated that all treated samples had significantly lower weight loss than untreated samples, and that there was not significant difference in the weight losses among samples treated with the preservatives. The same T-test results were also observed for the rating termite grade. The average grade against subterranean termite (Coptotermes curvignathus Holmgren) increased to be rating 10 near the pith and 9.4 near the bark after preservative treatments. Treated stakes, especially with retentions above $6 \mathrm{~kg} / \mathrm{m}^{3}$ (Fig. 6), were observed to resist termite attack and also lasted for a period of four months, which contrasts with the untreated stakes failing before the end of this period. This is due to the protection offered by cypermethrin in Enborer and carbendazim and chlorotalonyl in Entiblu to the treated wood stakes, thus enhancing their resistance. Subterranean termites were observed and identified to attack the untreated wood samples, whereas no wood-destroying fungi attack was observed in the samples. Varying degrees of damage from pith to bark, especially by the subterranean termite, were observed on the untreated stakes (Fig. 8a). Merkusii pine stakes that met standard retention requirement (above $6 \mathrm{~kg} / \mathrm{m}^{3}$ ) before being exposed to field test were slightly degraded by the subterranean termites. This agrees with other works that reported that preservative treated woods placed in ground contact exposure resist the attack by both fungi and termite (Cryptotermes cavifrons Bank), thus extending its service life compared with the untreated wood (Clausen and Green, 2003; Ukoima and Uko, 2013).

Considering that the heartwood portion of merkusii pine at the age of 40 years was around 65\%, together with the results presented above, merkusii pine should not be expected to exhibit remarkably inferior shrinkage and strength compared to other wood species, although it is less durable. Its lower decay resistance would restrict its utilization to some extent, although it might still be superior to many other less resistant timbers of fast-growing plantations like Indonesian Sengon (Paraserianthes falcataria) and Jabon (Anthocephalus cadamba), which are widely used. The future for merkusii pine wood preservation looks very promising. There are already many new wood substitutes for solid 

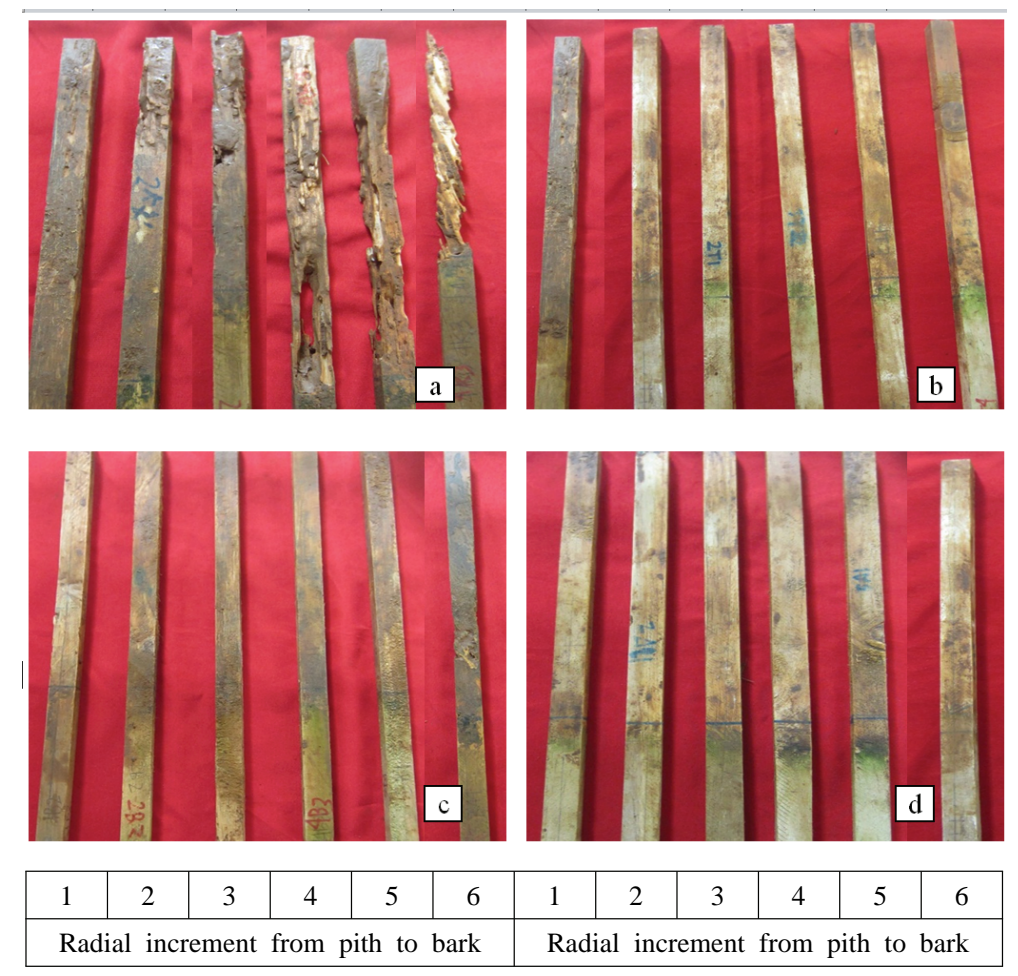

Fig. 8. Appearance of untreated (a) and enborer (b), entiblu (c), and combination (d) preservative-treated stakes of Merkusii pine from pith to bark against subterranean termites after three months graveyard test.

treated wood, including engineered wood composites like wood-plastic composites and products such as preserved oriented strandboard (OSB), laminated veneer lumber (LVL), and parallel strand lumber (PSL). All these products will require both new and existing preserving technologies to prevent the colonization by decay organisms and infestation by wood-destroying insects. Evaluation of engineered wood composites already in service has demonstrated that those without preservation have exhibited both mold and fruiting bodies after exterior exposure.

\section{CONCLUSION}

Fiber length and microfibril angle appear to be good anatomical indicators of age demarcation between juvenile and mature wood for merkusii pine. Demarcation points were at radial increment 14 by the fiber length and 12 by MFA. The projected figures for the portion of juvenile wood at breast height at the ages tested were $60 \%$. Density and static bending strength (MOE/MOR) of merkusii pine were found to increase from pith to bark. Both untreated heartwood and sapwood of merkusii pine were rated to be grade 4 to 0 regarding decay resistance against subterranean termite, which restricts its utilization to some extent for both indoor and outdoor applications. However, the use of chemical preservatives with standard retentions can enhance its rating to grade 10 to 9 . Merkusii pine is a medium density wood, readily treated with preservatives, its stability and bending strength are good, and therefore it can be used for many applications. 


\section{ACKNOWLEDGMENT}

The authors thank the Directorate for Research and Community Service of the Ministry of RISTEK DIKTI (011/SP2H/LT/DRPM/IV/2017) for the Republic of Indonesia for the research grant.

\section{REFERENCES}

Adamopoulos, S., Passialis, C., Voulgaridis, E. 2007. Strength properties of juvenile and mature wood inblack locust (Robiniapseudo acacia). Wood Fiber Science 39(2): 241-249.

Adamopoulos, S., Karageorgos, A., Passialis, C., Chavenetidou, M. 2011. Mathematical approach for defining juvenile-mature wood transition zone in black locust and chestnut. Wood Fiber Science 43(3): 336-342.

ASTM. 2005. Standard test methods for Evaluating Preservatives by Field Test with Stakes. American Society for Testing and Materials Standard D1758 - 05, Philadelphia. Published January 2015.

BSI. 1957. Standard test methods for Small Clear Specimens of Timber. British Standards Institution BS 373-1957. Published February 21, 1957.

Biblis, E.J. 1990. Properties and grade yield of lumber from a 27-year-old slash pine plantation. Forest Products Journal 40(3): 21-24.

Carter, F.L., Garlo, A.M., Stanely, J.B. 1978. Termiticidal components of wood extracts: 7-methyl-juglone from Diospyros virginiana. Journal of Agricultural and Food Chemistry 26: 869-887

Chang, S.T., Wang, S.Y., Wu, C.L., Su, Y.C., Kuo, Y.H. 1999. Antifungal compounds in the ethyl acetate soluble fraction of the extractives of Taiwania (Taiwania cryptomerioides Hayata) heartwood. Holzforschung 53(5): 487-490.

Clark, A., Daniels, R.F., Jordan, L. 2006. Juvenile mature wood transition in loblolly pine as defined by annual radial increment specific gravity, proportion of latewood, and microfibril angle. Wood Fibre Science 38(2): 292-299.

Clausen, C.A., Green, F.I. 2003. Copper tolerance of brown-rot fungi: Time course of oxalic acid production. International Bio deterioration and Biodegradation 51: 145-149.

Choong, E.T., Fogg, P.J. 1972. Variation in permeability and treatability of shortleaft pine and yellow poplar. Wood and Fiber Science 4(1): 2-12.

Darmawan, W., Rahayu, I., Nandika, D., Marchal, R. 2013. Determination of juvenile and mature transition ring for fast growing sengon and jabon wood. Journal of the Indian academy of wood science 10(1): 39-47.

Evans, J., Senft, J.F., Green, D.W. 2000. Juvenile wood effect in red alder: analysis of physical and mechanical data to delineate juvenile and mature wood zones. Forest Products Journal 50: 75-87.

Fajriani, E., Ruelle, J., Dlouha, J., Fournier, M., Hadi, Y.S., Darmawan, W. 2013. Radial variation of wood properties of Sengon (Paraserianthes falcataria) and Jabon (Anthocephalus cadamba). Journal of the Indian academy of wood science 10(2): 110-117.

Gapare, W.J., Wu, H.X., Abarquez, A. 2006. Genetic control of the time of transition from juvenile to mature wood in Pinusradiata D. Don. Annals of Forest Science 63(8): 871-878.

Gierlinger, N., Wimmer, R. 2004. Radial distribution of heartwood extractives and lignin in mature european larch. Wood and Fiber Science 36(3): 387-394

Gryc, V., Vavrcik, H., Horn, K. 2011. Density of juvenile and mature wood of selected coniferous species. Journal of Forest Science 57(3): 123-130.

Johansson, M., Kliger, R. 2002. Influence of material characteristics on warp in Norway spruce studs. 
Wayan Darmawan • Dodi Nandika • Britty Datin Hasna Afaf - Istie Rahayu - Dumasari Lumongga

Wood Fiber Science 34(2): 325-336.

Kim, D.W., Hwang, S.W., Lee, W.H. 2014. A Study on The Mechanical Properties of Korean Red Pine (Geumgangsong, Pinus densiflora forma erecta Uyeki). Journal of the Korean Wood Science and Technology 42(1): 58-67.

Kliger, R. 2001. Spiral grain on logs under bark reveals twist prone raw material. Forest Products Journal 51(6): 67-73.

Koubaa, A., Isabel, N., Shu Yin, Z., Beaulieu, J., Bousquet, J. 2005. Transition from juvenile to mature wood in black spruce (Picea Mariana (Mill.). Wood Fibre Science 37(3): 445-455.

Kretschmann, D.E., Bendtsen, B.A. 1992. Ultimate tensile stress and modulus of elasticity of fastgrown plantation loblolly pine lumber. Wood Fiber Science 24(2): 189-203.

Kwon, O., Lee, M.R., Eom, C.D. 2013. Utilization of Light Microscopy and FFT for MFA Measurement from Unstained Sections of Red Pine (Pinus densiflora). Journal of the Korean Wood Science and Technology 41(5): 399-405.

Lachenbruch, B., Moore, J.R., Evans, R. 2011. Radial variation in wood structure and function in woody plants, and hypotheses for its occurrence. Size and age-related changes in tree structure and function. Tree Physiology 4: 121-164.

Lee, A.H., Jang, J.H., Hwang, W.J., KIM, N.H. 2017. Decay and Termite Resistance of Yellow-Hearted Pine (Pinus densiflora for. erecta Uyeki) Journal of the Korean Wood Science and Technology 45(1): 12-19.

Martawijya, A., Kartasujana, I., Kadir, K., Prawira, S. 2005. Atlas Kayu Indonesia. Forest Products Research Institute, Bogor.

Mcdaniel, C.A. 1992. Major antitermitic components of the heartwood of Southern catalpa. Journal of Chemical Ecology 18(3): 359-369

MacPeak, M.D., Burkart, L.F., Weldon, D. 1990.
Comparison of grade, yield, and mechanical properties of lumber produced from young fast-grown and older slow-grown planted slash pine. Forest Products Journal 40(1): 11-14.

Mora, C.R., Lee Allen, H., Daniels, R.F., Clark, A. 2007. Modeling corewood-outerwood transition in loblolly pine using wood specific gravity. Canadian Journal of Forest Research 37: 999-1011.

Mutz, R., Guilley, E., Sauter, U.H., Nepveu, G. 2004. Modeling juvenile-mature wood transition in Scots pine (Pinus sylvestris L.) using nonlinear mixedeffects models. Annals of Forest Science 61: 831-841.

Teck, R.M., Hilt, DE. 1990. Individual-tree diameter growth model for the Northeastern United States, USDA Forest Service Research Paper NE-649

Santana, A.L.B.D., Maranhão, C.A., Santos, J.C., Cunha, F.M., Conceição, G.M., Bieber, L.W., Nascimento, M.S. 2010. Antitermitic activity of extractives from three Brazilian hardwoods against Nasutitermes corniger. International Biodeterioration \& Biodegradation 64: 7-12.

SAS Institute. 2004. SAS/STAT9.1 User's Guide, $1^{\text {st }}$ Ed. SAS Institute Inc., Cary, NC.

Sauter, U.H., Mutz, R., Munro, D. 1999. Determining juvenile-mature wood transition in scots pine using latewood density. Wood Fiber Science 31(4): 416-425.

Seo, J.W., Eom, C.D., Park, S.Y. 2014. Study on the Variations of Inter-annual Tracheid Length for Korean Red Pine from Sokwang-ri in Uljin. Journal of the Korean Wood Science and Technology 42(6): 646-652.

Shepard, R.K., Shottafer, J.E. 1992. Specific gravity and mechanical property-age relationships in red pine. Forest Products Journal 42(7/8): 60-66.

Stringer, J.W., Olson, J.R. 1987. Radial and vertical variation in stem properties of juvenile black locust. Wood Fiber Science 19(1): 59-67. 
TAPPI. 1991a. Tappi Test Methods: Morphological characteristics of pulp fiber under microscope ( $\mathrm{T}$ 401 om-88). Tappi Press, Atlanta, Georgia.

TAPPI. 1991b. Tappi Test Methods: Solvent Extractives of Wood and Pulp (T 204 om-88). Tappi Press, Atlanta, Georgia

Tasissa, G., Burkhart, H.E. 1998. Juvenile-mature wood demarcations in loblolly pine trees. Wood and Fiber Science 30(2): 119-127.

Taylor, A.M., Gartner, B.L., Morrell, J.J. 2006. Efects of heartwood extractive fractions of Thuja plicata and Chamaecyparis nootkatensis on wood degradation by termites or fungi. Journal of Wood Science 52: 147-153.

Tsoumis, G. 1991. Science and Technology of Wood: Structure, Properties, Utilization. $1^{\text {st }}$ ed. Van Nostrand Reinhold, New York.

Ukoima, N.H., Uko, E.R. 2013. Effect of chemical preservatives on service life of selected wood species treated against pests and diseases. Environment and Natural Resources Research 3(1): 157-163.

Wang, Q.A., Zhou, B., Shan, Y. 2004. Progress on antioxidant activation and extracting technology of flavonoids. Chemical Product Technology 11: 29-33

Winandy, J.E., Green, F., Keefe, D. 2001. Treatability problems-relationships between anatomy, chemical composition and treatability. IRG/WP 01-40213, IRG, Stockholm, Sweden

Zobel, B.J. 1984. The changing quality of the world wood supply. Wood Science and Technology 18: 1-7.

Zabel, R.A, Morrell, J.J. 1992. Wood microbiology Decay and its prevention. Academic Press, NY. 